\title{
Supply Chain Collaboration in Emerging Economies Moroccan Food, Textile and Leather Industries
}

\author{
BELHSEN Nour-Eddine, SENTEL OUSSAMA \\ High School of Management, Tangier, Morocco \\ BENMBAREK Houda \\ High School of Management, Agadir, Morocco
}

\begin{abstract}
The aim of this research is to examine the collaborative behaviors of key suppliers and its effects on logistics and organizational performance of food, textile, and leather industries in an emerging economy: Morocco. The qualitative study and quantitative one are done. Techniques of content analysis are applied using Nvivo 9 software for the first study. Survey research and structural equation modeling using LISREL 8.7 was done for the second one. The results of qualitative study indicate that the concepts used are mainly important in industries. Supply chain collaboration affects strongly logistics performance rather than organizational performance. Also, Logistics performance has a great effect on organizational performance. One of the aim limitations of the current research may have been the nature of scale chosen. Logistic and organizational Performance is formative factors not reflective measures. Moreover, we should distinct those construct into qualitative and quantitative dimensions. In order to achieve greater organizational performance, more attention should be paid on logistic performance more than supply chain collaboration.
\end{abstract}

Keywords: collaboration, logistics performance, organizational performance, emerging economy

\section{Introduction}

The globalization of markets, advances in technology have increased interconnection between countries and companies through the world. In this context, firm's competitiveness requires to optimize the performance of whole supply chains rather than individual organizations (Liker \& Choi, 2005; Sheu, Yen, \& Chae, 2006; Johnson \& Sohi, 2003). Two types of performance are often highlighted: logistics performance and organizational performance. In this context, inter-organizational collaboration becomes the cornerstone to achieve a high level of performance (Li et al., 2005).

In recent decades, supply chain collaboration is a major topic of research in logistics. Studies have dealt with several issues like the conceptualization of the construct, its antecedents, and its consequences. Research made in developed countries highlights that collaborative relationships within the supply chain facilitate access to information (Hsu et al., 2008), share risk (Wagner \& Bode, 2008), reduce logistics costs and transactions

BELHSEN Nour-Eddine, Associate Professor, Department of Marketing and Logistics, High School of Management.

SENTEL OUSSAMA, Ph.D. candidate, Department of Marketing and Logistics, High School of Management.

BENMBAREK Houda, Ph.D. candidate, Department of Marketing and Logistics, High School of Management.

Correspondence concerning this article should be addressed to BELHSEN Nour-Eddine, Department of Marketing and Logistics, High School of Management, Morocco. E-mail: n.belhsen@yahoo.com. 
(Stank, Keller, \& Daugherty, 2001), reduce the cost of the product; increase customer satisfaction, strength customer loyalty (Filbeck et al., 2005), improves product quality (Emerson \& Grimm, 1998), strengthen the competitive advantage of the firm (Jap, 2001; Dupuis \& Fournioux, 2005) and finally increase the performance of all firms in the supply chain (Fugate, Mentzer, \& Stank, 2010).

However, knowledge about supply chain collaboration derives almost exclusively from research conducted in United States and western Europe. Most of the replication studies have also been undertaken in the developed economies. As supply chain collaboration is not yet well investigated in developing countries; therefore, there is a need to replicate these studies in the emerging economies to compare empirical findings and contribute to the advances on supply chain collaboration theory. In other words, it is likely that the supply chain collaboration concept may not apply in a standard manner in an emerging economy.

The socio-economic, demographic, and especially cultural contexts in emerging economies are so different from those in developed countries. Then, the application of theoretical framework and empirical findings in emerging economies becomes less obvious. Burgess and Steenkamp (2006) noted that it was urgent to develop research in emerging markets because success in these markets is crucial for the future of many Western companies.

The key goal of this research is to examine the collaborative behavior of key suppliers and its effects on logistics and organizational performance in an emerging economy: Morocco. As a Arabic country, according to Hofstede (1997) in Dwairi, Bhuain, and Jurkus (2007), Morocco can be categorized as high on uncertainty avoidance, power distance, masculinity, and collectivism. A high level of uncertainty avoidance will inhibit innovative responses to changing market environment, a high level of power distance can be detrimental to effective and efficient market response. Further, a high level of masculinity can result in creating market information gap and ineffective market response. Finally, a high level of collectivism may hamper individual motivation and creativity that are essentials for innovative responses to changing market conditions. Moreover, in recent times, economic activities in terms of both contribution to the gross national product and employment have witnessed shift from manufacturing activities to service activities.

According to the previously exposed observations and reflections, we assert that environmental context of emerging economies can play a major role in the understanding and application of collaborative behavior.

As replication, hypotheses in this research are developed on the basis of studies done in western countries. The aim is to verify the relationship between collaborative behaviour, logistic performance, and organizational performance in two industries: food, textile and leather industries rather than to develop new concepts or measuring scales. Therefore, special attention was given to quantitative research. Those industries occupy a strategic place in the national economy and encompass more 30\% of companies established in Morocco. The public power holders have made great efforts to integrate those sectors in the industrial strategy of the Kingdom especially by targeting more foreign markets, attracting more foreign direct investment through numerous international logistics platform and finally engaging measures within framework of the Pact for Industrial Emergency. Then, interconnections between local and foreign companies become greater.

The rest of the paper is organized as follows: First, we survey relevant literatures regarding supply chain collaboration in developed countries and draw the research hypotheses; Second, we present the research methodology and results; Finally, conclusions and managerial implications are provided. 


\section{Theoretical Framework and Research Hypothesis}

\section{Collaborative Behavior}

The collaboration is a social phenomenon. It was examined by the researchers in sociology, psychology, marketing, management, and supply chain management (Min et al., 2005). Also, it was examined in transaction cost economics perspective (Nesheim, 2001; Barringer \& Harrison, 2000) resource-based theory (Park, Mezias, \& Song, 2004; Verwaal \& Hesselmans, 2004), institutional theory, resource dependence theory, the social exchange theory (Thomas \& Rangannathan, 2005).

Despite the importance of this concept, collaboration within the supply chain remains an elusive and polysemous concept. This greatly limits the ability of logistics managers to explain and assess the level of collaborative behavior of their partners including suppliers (Saeed, Malhotra, \& Grover, 2005).

Several authors stress for the establishment of the relations long-term collaborative between companies at various levels of the supply chain in order to deliver a good value to the customer (Gunasekaran, Patel, \& Tirtiroglou, 2001). Nowadays, the collaborative relations are a necessity more than a choice (Matopoulos, Vlachopoulou, \& Manthou, 2007).

The collaboration within the supply chain means two or several independent companies work together to plan the operations of the supply chain (Simatupang \& Sridharan, 2002). It involves the information sharing and resources, and risks (Barratt, 2004). The aim expected in the long term is the realization of the common objectives of the partner companies (Spekman, Kamauff, \& Myhr, 1998; Mentzer, Foggin, \& Golicic, 2000).

Drawing on the academic literature, supply chain collaboration is a long term partnership in which firms with common goals work closely together to achieve advantage greater than the firms would achieve individually. Data collected by the Supply Chain Council shows that excellent supply chain performance can lower costs by up to $7 \%$ and enhance cash-flow by more than $30 \%$. Collaboration, as the critical element, contributes to these performance improvements (Stank et al., 2001). Supply chain collaboration is widely considered by both practitioners and researchers a vital contributor to supply chain performance (Prajogo \& Olhager, 2012).

The collaborative behavior is practices expressed by companies to implement and concretize the collaborative relationships. Our research deals with the collaborative behavior of the key suppliers in Morocco as an emerging economy.

Authors like Kampstra, Ashayeri, and Gattorna (2006) call back the stages of development of inter organizational relationships: communication, collaboration, intensive collaboration, and partnership. We can assert that the communication is the cornerstone of the development of the best collaborative practices. Mohr and Spekman (1994) point out that the communication is a backbone for the success of the collaborative relationships.

A significant amount of research has focused on the benefits of supply chain collaboration on logistic and organizational performance.

\section{Logistic Performance}

The performance is a policeman concept, multidimensional and can measure it at various levels of the supply chain. This measurement is the cornerstone in the management of the operations of the information which allows the supply chain to take and operate the decisions. "No measure, no improvement" (Kaplan, 1990). In this respect, Harrington (1995) notes that "If you cannot measure the performance logistics, we 
cannot control it and if we cannot control it, it would be difficult to manage it and thus we cannot improve it". More clearly, Keebler and Plank (2009) specify three reasons for which the company has to measure its logistic performance: reduce the costs, increase the turnover and the financial performance, and plead for a clear and precise measure of this concept.

Several definitions are very often proposed, accompanied with a measure. The consensus concerning the dimensionality and the measure of the concept has not been achieved (Gunasekaran \& Kobu, 2007). According to Mentzer and Konrad (1991) logistic performance is the efficiency and effectiveness in the realization of the logistic activities. Other scholars (Fugate et al., 2010) developed the third dimension like the differentiation. They assert that the customer value resulting from logistic activities also serves as an indicator of the performance. They assert that the logistics can create value by the efficiency, the effectiveness, and the differentiation. A superior logistic performance requires superiority with regard to the competitors: the differentiation.

Despite of the lack of consensus among scholars concerning the definition and the measure of logistic performance, agreement seems to be emerging on its effect on organizational performance. Thus, Kluyver and Pearce (2006) remind that the objective of long-term business relationship is to have superior. This requires an implementation of a strategy of the supply chain to integrate and coordinate all the internal processes and the external one in order to offer a superior value to the customer (Cohen \& Roussel, 2005). Also, Rutner and Langley (2000) note that the logistic function plays an undeniable role in the organizational performance. These comments above drive us to formulate the following hypothesis.

\section{Organizational Performance}

The performance of company is a central notion in sciences of management. The performance constitutes the reason for being of any company. Since the 80 s, several researchers attempted to define it (Bescos, 1998; Bessire, 1999). Following the example of the concepts of behavior collaborative and of the logistic performance, the organizational performance suffers from this lack of its definition and its measure. However, we can note that historically, the evaluation of the performance bases itself on financial criteria. In USA, This vision changed with the decline of the American industry in 1980 (Johnson \& Kaplan, 1987). The authors retain two phases in the development of the literature on the measures of the performance: Before the year 1980: purely financial measures (profit, turnover, return on investment); and after 1980: quantitative measures (financial) and qualitative ones (Saad, 2006): quality of products - the customer satisfaction. The integration of last measures is understandable by the fact that they determine the former one (Banker, Potter, \& Srinivasan, 2000). In this context, Kaplan and Norton (1996) note the necessity of taking into account the qualitative measure in the evaluation of the organizational performance. These authors proposed an indicator which became the most popular: the balanced scorecard (BSC). In its original presentation, this indicator includes four axes:

- The first one reserved for the finance that is focused on quantitative criteria;

- The second concerned the customer that is centred on the determiners of the customer satisfaction;

- The third is connected with the internal process which sends back to the management of the operations and the processes source of competitive advantage;

- The fourth is inherent to the organizational learning centred on the mode of management implemented to reach the expected strategic objectives. 
Based on previous research presented above, three hypotheses were developed and depicted in Figure 1.

H1: In emerging economies, supplier's collaborative behaviors and logistic performance are positively related.

H2: In emerging economies, supplier's collaborative behaviors and organizational performance are positively related.

H3: High levels of logistics performance are positively associated with high levels of organizational performance in emerging economies

The research model and research hypothesis are depicted in Figure 1.

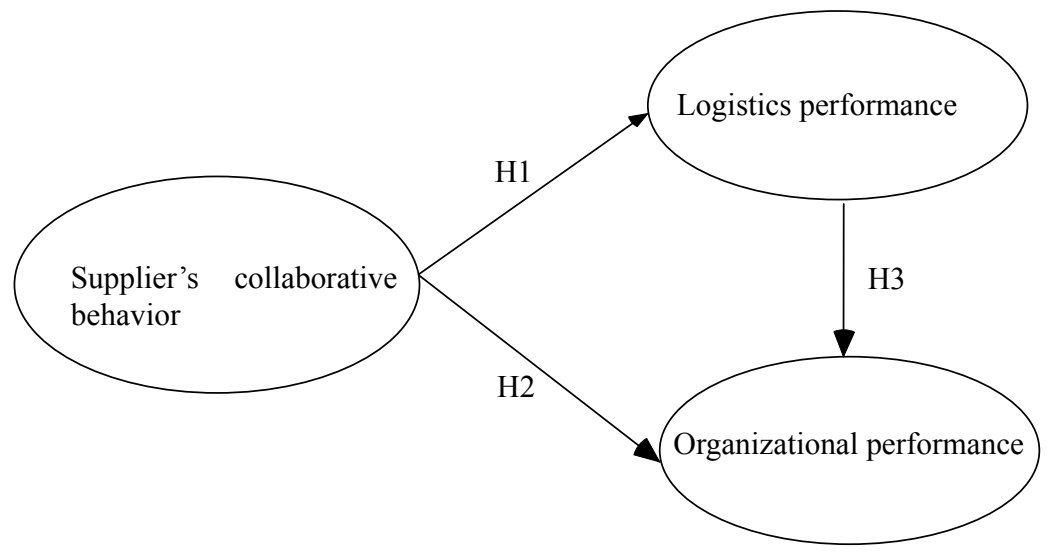

Figure 1. Conceptual model.

\section{Research Methodology}

In answering our research question, we conducted a pilot study using in-depth interviews and survey questionnaire.

\section{A Pilot Study}

To the best of our knowledge, the literature on collaborative practices is very limited or even nonexistent in Morocco as an emerging economy; we conducted a pilot study. Two objectives are expected; first check the existence, the description, and the perception of these practices and their consequences among logistics managers and/or directors of industrial firms in two Moroccan industrial cities: Casablanca and Tangiers.

As supply chain collaboration focus on the joint relationship, the theoretical constructs identified in this study are used to study the dyadic collaborative behavior between manufacturers and their primary/key suppliers. The sample size has been defined according to the principle of theoretical saturation (Strauss \& Corbin, 1990). A total of 21 semi-structured interviews were conducted between April 2011 and July 2011 (see Table 1). The average length of each interview is 40 minutes. The interview guide was designed progressive and drawing on the conceptual framework developed by western researchers. We should note that we interviewed the logistics managers of companies operating in the fields of textile, leather and food industries.

Table 1

Sample Interviewed

\begin{tabular}{lcc}
\hline Cities & Textile, leather & Food \\
\hline Casablanca & 6 & 4 \\
Tangier & 5 & 6 \\
Total & 11 & 10 \\
\hline
\end{tabular}


We sent an email to a sample of 70 companies asking for an appointment for an interview. Follow-up phone calls and face to face contact were made. In the e-mail, we briefly introduced the study, its objectives, managerial implications, and our parent organization and stressed the confidentiality and anonymity of responses. Once a company agreed to participate, a copy of the interview protocol was provided. Ultimately, 21 managers have agreed to meet us. During each interview, extensive notes were made for later analysis and where necessary, translation, and transcription. During the interview, the participants were asked to give their point of view about the constructs underlying our model and their relevance in doing their activities.

In qualitative research, textual data is the most important information source. Technique of content analysis is applied using Nvivo 9 software following the different steps suggested by Miles and Huberman (1994): data reduction, data display, and conclusion drawing/verification. The results show that both suppliers and buyers are both concerned about the logistical and organizational performance. The quantitative and qualitative indicators, absolute, and relative, are displayed in the discourse of the interviewees. Market share and financial profitability; reduce costs, lead times, improved quality, effectiveness and efficiency are the most concepts emerged. Similarly, buyers recognize that this performance may have different internal determinants: resources and competitive advantages; and external such as the quality of the relationship with suppliers and customers. Logistics is a concept present in the discourse of the interviewees. Logistics is seen as all transactions made by the company with third parties. Moreover, logistics is defined as transportation activities for exporting and importing companies, this is explained by its effect on the cost of the product, product quality and deadlines. Collaboration is mentioned in relations with suppliers and not with customers. This collaboration is understood broadly as a means to improve the quality of inputs: raw materials, quality, delivery time, frequency of replenishment, price. It is manifested by the visit of suppliers, regular exchange of information on the activity sector. The trust and satisfaction are two elements that determine a strong collaborative relationship. The performance is presented as a result of the quality of these inputs and also of the internal competitive advantage of the company.

In conclusion of this pilot study, we can assert that the model, used in studies done in western countries, can be tested in emerging economies.

\section{Quantitative Study}

Remember that the aim of our research is to test the causal relationships between variables in the model and not develop new scales. For this purpose, we developed a questionnaire following the research done by Cao and Zhang (2011) and Cao et al. (2010) and used the results of the qualitative study. Thus, 16 items were generated. The scales used by these authors are in English. To dispose of items in French, we followed the methods advocated by Besson and Haddadj (2003): translation English-French and back translation French-English (back translation) in blind by two translators.

Six items were generated to measure the collaborative behavior, five items for the logistic performance and five items for the organizational performance. The answering scale used is a five point Likert scale ranging from (1) totally disagree to (5) totally agree. Moreover, the common pool of items was reviewed and evaluated by practitioners from four different manufacturing firms to pre-assess the reliability and validity of the scales. Two professors specializing in business to business management have also examined the questionnaire. Based on the feedback from the expert, redundant and ambiguous items were eliminated or modified. In total, our questionnaire includes 13 items. 
For data collection, we combined different techniques: mailing, personal network, professional associations, and mobilized students. Data collection was conducted in October, November, and December 2011 in two major industrial cities of the Kingdom: Casablanca and Tangier, 3,250 questionnaires were administered to CEOs, presidents, directors, or logistics managers of two industries: food processing and textile and leather. A total of 610 questionnaires were collected, 30 incomplete responses received. The response rate is $19 \%$. Finally, 580 questionnaires are analyzed. Characteristics of the respondents are shown in Table 2.

Table 2

Respondent' Characteristics

\begin{tabular}{llllllll}
\hline \multirow{2}{*}{ Total of questionnaire } & \multicolumn{3}{c}{ CEO, Vice presidents } & & \multicolumn{3}{c}{ Directors or logistics managers } \\
\cline { 2 - 4 } \cline { 6 - 8 } & Sent & Received & Response rate & & Sent & Received & Response rate \\
\hline Textile, leather & 100 & 20 & 0.20 & & 1,100 & 240 & 100 \\
Food & 150 & 24 & 0.16 & & 1,900 & 326 & 150 \\
Total & 250 & 44 & 0.18 & & 3,000 & 566 & 250 \\
\hline
\end{tabular}

\section{Results and Discussions}

To test our conceptual model, we performed a series of exploratory factor analysis (EFA) to check the psychometric quality of the variables and confirmatory analyzes to test hypotheses.

\section{Results of Exploratory Factor Analysis}

An exploratory factor analysis (EFA) by principal component analysis (PCA) with oblique rotation using SPSS 17.0 was done. Two items for collaborative behaviour, one item for logistics performance and one item for organizational performance were deleted from further analyses because they had factor loading that were lower than the cut-off of 0.5 .

The total variance explained was greater than the required merging of 0.6. The reliability assessment of each theoretical construct, before and after removed items, was performed. The result shows the good reliability of the data collected for the study; the Cronbach's alphas of each factor were statistically strong; the factor one (collaborative behavior) value was 0.8604 , factor two (logistics performance), value was 0.7112 , and factor three (organizational performance) value was 0.6869 . The results are reported in Table 3.

Table 3

Exploratory Factor Analysis Results for Collaborative Behavior, Logistics and Organizational Performances

\begin{tabular}{lllllllll}
\hline \multirow{2}{*}{ Variables } & \multicolumn{3}{c}{ Before the removal of items misrepresented } & \multicolumn{3}{c}{ After the removal of items misrepresented } \\
\cline { 2 - 9 } & $\begin{array}{l}\text { Number } \\
\text { of item }\end{array}$ & KMO & $\begin{array}{l}\text { variance } \\
\text { explained (\%) }\end{array}$ & $\begin{array}{l}\text { Alpha de } \\
\text { cronbach }\end{array}$ & $\begin{array}{l}\text { Number } \\
\text { of items }\end{array}$ & KMO & $\begin{array}{l}\text { variance } \\
\text { explained (\%) }\end{array}$ & $\begin{array}{l}\text { Alpha de } \\
\text { cronbach }\end{array}$ \\
\hline Collaborative behavior & 5 & 0.809 & 58.088 & 0.5985 & 3 & 0.728 & 78.378 & 0.8604 \\
Logistics performance & 4 & 0.714 & 55.051 & 0.6135 & 3 & 0.644 & 63.476 & 0.7112 \\
Organizational performance & 4 & 0.716 & 52.109 & 0.596 & 3 & 0.647 & 61.978 & 0.6869 \\
\hline
\end{tabular}

\section{Results of Confirmatory Analyzes}

Confirmatory analyzes were conducted by using techniques of structural equations (SEM). SEM consists of a measurement model that specifies the relationship between the observed measures and their latent constructs, and the structural model that specifies the causal relationships between the latent constructs themselves (Hair et al., 1998). The implementation of these techniques requires an approach on two-step 
(Anderson \& Gerbing, 1988): first validations of measurement models and then test the structural model as a whole. These analyzes were performed using the software LISREL 8.7.

\section{Validation of the Measurement Model}

After eliminating items poorly represented, we evaluate the overall fit of the models, several fit indices were employed. These included chi-square per degree of freedom, root mean square error of approximation (RMSEA), goodness-of-fit index (GFI), Tucker-Lewis Index (TLI), comparative fit index (CFI), and Root Mean Square Residual (RMR). For GFI, AGFI, CFI, TLI there is a general agreement that the values of 0.95 or greater indicate a satisfactory fit to the data (Schumacker \& Lomax, 2004). The values of both RMR and RMSEA below 0.08 and 0.06 respectively represent acceptable model-data fit (Hu \& Bentler, 1999). Moreover, for chi-square per degree of freedom, a value less than 3.0 indicates a reasonable fit (Papke-Shields, Malhotra, \& Grover, 2002).

The results of CFA are displayed in Table 4 and they give evidence for a good fit with the data. However, all items have quite substantial and significant loadings on their respective factor, which indicates the convergent validity of the items. The average extracted variance values for each dimension are well above the recommended threshold of 0.5 , thus supporting the convergent validity of the three dimensions. The results of rho of Joreskog show a good reliability for each factor (see Table 5).

Table 4

Confirmatory Factor Analysis Results

\begin{tabular}{llllllcc}
\hline Variables & Normed $\chi^{2}$ & RMSEA & CFI & TLI & GFI & AGFI & RMR \\
\hline Collaborative behavior & 1.08 & 0.049 & 0.987 & 0.988 & 0.975 & 0.963 & 0.04 \\
Logistics performance & 2.12 & 0.064 & 0.992 & 0.986 & 0.980 & 0.949 & 0.03 \\
Organizational performance & 2.21 & 0.03 & 0.994 & 0.984 & 0.982 & 0.954 & 0.05 \\
\hline
\end{tabular}

Table 5

Convergent Validity and Reliability

\begin{tabular}{lll}
\hline Variables & Rhô of Jöreskog & Average variance extracted \\
\hline Collaborative behavior & 0.8668 & 0.6879 \\
Logistics performance & 0.7012 & 0.5518 \\
Organizational performance & 0.6922 & 0.5347 \\
\hline
\end{tabular}

Table 6

Path Coefficients and T-Values

\begin{tabular}{lll}
\hline & Coefficients & $T$ value \\
\hline Collaborative Behavior $\leftarrow$ Logistics Performance & 0.61 & 10.18 \\
Collaborative Behavior $\leftarrow$ Organizational Performance & 0.12 & 1.93 \\
Logistics Performance $\leftarrow$ Organizational Performance & 0.75 & 7.9 \\
\hline
\end{tabular}

The results of structural model provided acceptable overall fit: chi-square of 126, 22, and degree of 42. GFI, AGFI, CFI, TLI are respectively 0.97 ; $0.98 ; 0.98$ and 0.95 . RMSEA value is 0.07 .

The path diagram and the loadings using LISREL 8.5 are shown in Figure 2. The result supports Hypothesis 1 . The standardized coefficient is $0.61(t=10.18)$, which is statistically significant at the level of 0.01 (see Table 6). Thus, the supplier's collaborative behavior has a positive and direct effect on logistics performance. Hypothesis 3 is confirmed. The LISREL path coefficient is $0.75(t=7.9)$, which statistically good 
at the level of 0.01 . The logistics performance has a strong effect on organizational performance. Hypothesis 2 is also supported at the level of 0.01 , the coefficient is poor $(0,12)$ showing that collaborative behavior of suppliers does not strongly affect the organizational performance.

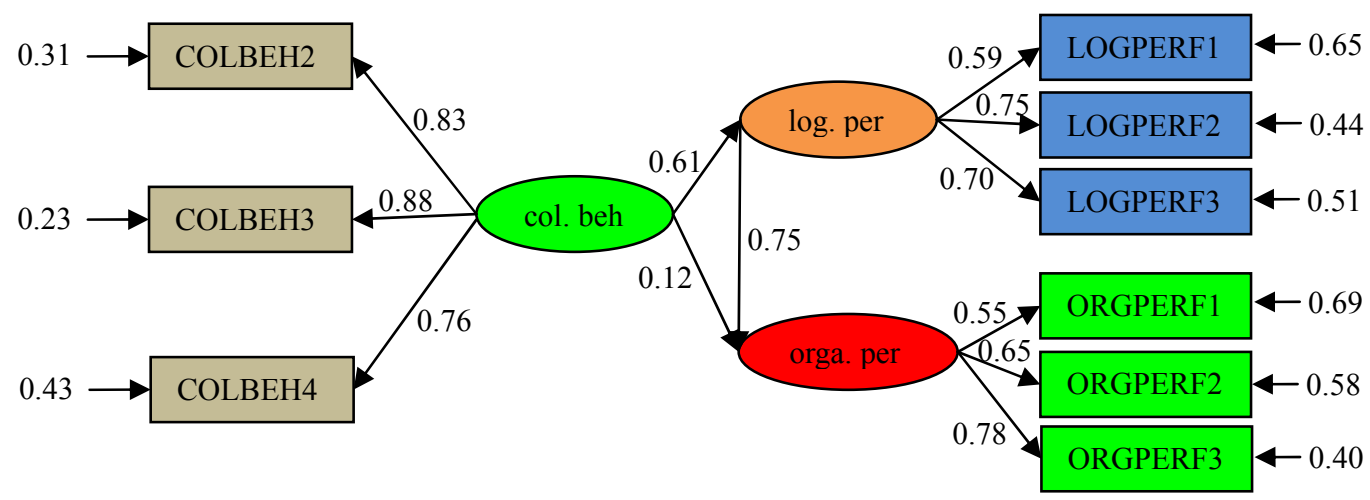

Figure 2. Hypotheses test using structural equation model (Path and measurement)

\section{Conclusions and Implications}

The researchers in social sciences plead for the integration of developing economies as breeding grounds of empirical investigation. The majority of the research in logistics was driven in the United States and in Western Europe, now we cannot neglect the emerging countries where lives more than $80 \%$ of the consumers (Steenkamp \& Burgess, 2002). In this frame, two main objectives were assigned to this research. At first, verify the mediating role of the logistic performance and then test the effect of the collaborative behavior on the organizational performance in a developing country especially in Morocco. The empirical study was realized with a sample of 580 companies operating in the agro food sector and that of the textile industry and the leather. The results show that the collaborative behavior has more considerable effect on the logistic performance than on the organizational performance. So, a very strong effect of the logistic performance on the organizational performance was verified. This result is consistent with previous research (Fugate et al., 2010; Green et al., 2008). Our research is of causal nature. We can indicate that the evaluation of the logistic performance should be based on indicators other than quantitative such as the quality of the logistic departments in particular for the fresh food-processing products. Also, a good logistic performance which is the cornerstone of the organizational performance bases on the collaborative behavior of the suppliers. Thus, an improvement of the relationship quality with the suppliers of the inputs (Raw materials, price, deadline, and conditions of delivery etc.) through regular visits is important. So, the division of the knowledge, the role of information systems (enterprise resource planning, advanced planning system, supply chain execution) and the integration and the Electronic Data Interchange (EDI) are the cornerstone for a good management of the relation supplier. The results imply managerial implications (Lambin, 1998) for companies from emerging and developed countries.

This research sheds light on the perception and applications of collaborative behavior in Morocco. The results are highly useful for the Moroccan companies as well as for their partners in western countries. Besides, Moroccan presents an attractive site for foreign investment together with strong traditions of business with Europe. In this respect, interactions exist between western companies and Moroccan ones, and they are characterized by different levels of collaboration. 
While the research has made significant contributions to research and practice, there are limitations that need to be considered when interpreting the study findings. They offer perspectives for future researches. Choices done in the measure of variables, we were inspired by works of Cao and Zhang (2011), Cao et al. (2010). This concept measure was tried in contexts different from the food-processing industry and the sector of the textile and the leather. The use of measure developed by other scholars could possibly modify the results of our research. We supposed that the logistic performance and the organizational performance are two reflective indications that authors (Fugate et al., 2010) consider that they are formative.

\section{References}

Anderson, J., \& Gerbing, D. (1988). Structural equation modeling in practice: A review and recommended two-step approach. Psychological Bulletin, 103(3), 411-423.

Banker, R. D., Potter, G., \& Srinivasan, D. (2000). An empirical investigation of an incentive plan that includes non financial performance measures. The Accounting Review, 75(1), 65-92.

Barratt, M. (2004). Understanding the meaning of collaboration. Supply Chain Management: An International Journal, 9(1), $30-42$.

Barringer, B. R., \& Harrison, J. S. (2000). Walking a tightrope: Creating value through interorganizational relationships. Journal of Management, 26(3), 367-4403.

Baumeister, R. F. (1993). Exposing the self-knowledge myth. Contemporary Psychology, 38, 466-467.

Bescos, P. L. (1998). La méthode ABC est-elle utile aux PME? Revue Franaçise de Comptabilité, 305(98), $32-42$.

Bescos, P., Dobler, P., Mendoza, C., \& Naulleau, G. (1993). Contrôle de gestion et management (2nd ed.). Montchrestien.

Bessire, D. (1999). Définir la performance. Comptabilité-Contrôle-Audit, 5(2), 127-150.

Besson, D., \& Haddadj, S. (2003). Adaptation internationale des échelles de mesure entre universalisme et culturalisme: Application à la mesure de l'environnement de l'entreprise". Proceedings from XIIème Conférence de l'Association Internationale de Management Stratégique, Les Côtes de Carthage.

Burgess, S. M., \& Steenkamp, E. M. (2006). Marketing renaissance: How research in emerging markets advances marketing science and practice. International Journal of Research in Marketing, 23, 337-356.

Cao, M., \& Zhang, Q. (2011). Supply chain collaboration: Impact on collaborative advantage and firm performance. Journal of Operations Management, 29, 163-180.

Cao, M., Vonderembse, M. A., Zhang, Q., \& Ragu-Nathan, T. S. (2010). Supply chain collaboration: Conceptualization and instrument development. International Journal of Production Research, 48(22), 6613-6635.

Cauvin, E., \& Bescos, P. L. (2005). Les déterminants du choix des indicateurs dans les tableaux de bord des entreprises: Une étude empirique. Finance Contrôle Stratégie, 8(1), 5-25.

Cohen, S., \& Roussel, J. (2005). Strategic supply chain management: The five disciplines for top performance. New York, N.Y.: McGraw-Hill.

Das, T. K., \& Teng, B. S. (1998). Between trust and control: Developing confidence in partner cooperation in alliances. Academy of Management Review, 23(3), 491-512.

Duncan, G. J., \& Brooks-Gunn, J. (1997). Consequences of growing up poor. New York, N.Y.: Russell Sage Foundation.

Dupuis, M., \& Fournioux, J. (2005). Internationalisation du distributeur: De l'avantage compétitif à la performance. Décisions Marketing, 36(1), 45-56.

Dwairi, M. A., Bhuain, S. N., \& Jurkus, A. (2007). Revisiting the pioneering market orientation model in an emerging economy. European Journal of Marketing, 41(7/8), 713-721.

Emerson, C. J., \& Grimm, C. M. (1998). The relative importance of logistics and marketing customer service: A strategic perspective. Journal of Business Logistics, 19(1), 17-32.

Filbeck, G., Gorman, R., Greenlee, T., \& Speh, T. (2005). The stock price reaction to supply management advertisements and company value. Journal of Business Logistics, 26(1), 199-216.

Fugate, B. S., Mentzer, J. T., \& Stank, T. P. (2010). Logistics performance: Efficiency, effectiveness, and differentiation. Journal of Business Logistics, 31(1), 43-62.

Fynes, B., de Búrca, S., \& Marshall, D. (2004). Environmental uncertainty, supply chain relationship quality and performance. Journal of Purchasing and Supply Management, 10(4/5), 179-190. 
Green, K. W., Whitten, D., \& Inman, A. R. (2008). The impact of logistics performance on organizational performance in a supply chain context. Supply Chain Management, 13(4), 317-327.

Gunasekaran, A., \& Kobu, B. (2007). Performance measures and metrics in logistics and supply chain management: A review of recent literature (1995-2004) for research and applications. International Journal of Production Research, 45(12), 2819-2840.

Gunasekaran, A., Patel, C., \& Tirtiroglou, E. (2001). Performance measure and metrics in a supply chain environment. International Journal of Operations and Production Management, 21(1/2), 71-87.

Hair, J. F., Anderson, R. E., Tatham, L., \& Black, W. C. (1998). Multivariate data analysis with readings (5th ed.). Upper Saddle River, N.J.: Prentice-Hall.

Harrington, L. H. (1995). Logistics, agent for change: Shaping the integrated supply chain. Transportation and Distribution, 36(1), 30-34.

Heizer, J., \& Render, B. (2006). Operations management. Upper Saddle River, N.J.: Pearson Education, Inc.

Helfer, M. E., Keme, R. S., \& Drugman, R. D. (1997). The battered child (5th ed.). Chicago, I.L.: University of Chicago Press.

Henry, W. A. (1990). Making the grade in today's schools. Time, 135, 28-31.

Hsu, C. C., Kannan, V. R., Tan, K. C., \& Leong, K. (2008). Information sharing, buyer-supplier relationships, and firm performance: A multi-region analysis. International Journal of Physical Distribution and Logistics Management, 38(4), 296-310.

Hu, L., \& Bentler, P. M. (1999). Cutoff criteria for fit indexes in covariance structure analysis: Conventional criteria versus new alternatives. Structural Equation Modeling, 6, 1-55.

Jap, S. D. (2001). Perspectives on joint competitive advantages in buyer-supplier relationships. International Journal of Research in Marketing, 18(1/2), 19-35.

Johnson, H., \& Kaplan, R. (1987). Relevance lost: The rise and fall of management accounting. Boston, M.A.: Harvard Business School Press.

Johnson, J. J., \& Sohi, R. S. (2003). The development of interfirm partnering competence: Platforms for learning, learning activities and consequences of learning. Journal of Business Research, 56(9), 757-766.

Kampstra, R. P., Ashayeri, J., \& Gattorna, J. (2006). Realities of supply chain collaboration. The International Journal of Logistics Management, 17(3), 312-330.

Kaplan, R., \& Norton, D. (1996). The balanced scorecard. Boston, M.A.: Harvard Business School Press.

Keebler, J. S., \& Plank, R. E. (2009). Logistics performance measurement in the supply chain: A benchmark. Benchmarking: An International Journal, 16(6), 785-798

Kluyver, C. A., \& Pearce, J. A. (2006). Strategy: A view from the top (2nd ed.). New Jersey: Upper Saddle River.

Lambin, J. J. (1998). Le marketing stratégique—Du marketing à l'orientation-marché. Paris: Ediscience International.

Laplace, P. S. (1951). A philosophical essay on probabilities. New York, N.Y: Dover.

Li, S., Rao, S. S., Ragu-Nathan, T. S., \& Ragu-Nathan, B. (2005). Development and validation of a measurement instrument for studying supply chain management practices. Journal of Operations Management, 23(6), 618-641.

Liker, J. K., \& Choi, T. Y. (2005). Building deep supplier relationship. Harvard Business Review, 83(1), 104-113.

Matopoulos, A., Vlachopoulou, M., \& Manthou, V. (2007). A conceptual framework for supply chain collaboration: Empirical evidence from the agri-food industry. Supply Chain Management: An International Journal, 12(3), 177-186.

Mentzer, J. T., \& Konard, B. P. (1991). An efficiency/effectiveness approach to logistics performance. Journal of business logistics, 12(1), 33-62.

Mentzer, J. T., Foggin, J. H., \& Golicic, S. G. (2000). Supply chain collaboration: Enablers, impediments and benefits. Supply Chain Management Review, 4, 52-58.

Miles, M. B., \& Huberman, A. M. (1994). Qualitative data analysis: An expanded sourcebook (2nd ed.). Thousand Oaks, C.A.: Sage Publications.

Min, S., Roath, A. S., Daugherty, P. J., Genchev, S. E., Chen, H., Arndt, A. D., \& Richey, R. G. (2005). Supply chain collaboration: What's happening. The International Journal of Logistics Management, 16(2), 237-256.

Mohr, J. E., \& Spekman, R. E. (1994). Characteristics of partnership success: Partnership attributes communication behavior and conflict resolution techniques. Strategic Management Journal, 15(2), 135-152.

Moller, M. M., Johanson, J., \& Boer, H. (2003). Managing buyer-supplier relationships and inter-organizational competence development. Journal of Manufacturing Technology Management, 14(4), 369 -379. 
Nesheim, T. (2001). Externalization of the core: Antecedents of collaborative relationships with the suppliers. European Journal of Purchasing and Supply Management, 7(4), 217-225.

Papke-Shields, K. E., Malhotra, M. J., \& Grover, V. (2002). Strategic manufacturing planning systems and their linkage to planning system success. Decision Sciences, 33(1), 1-30.

Park, N. K., Mezias, J. M., \& Song, J. (2004). A resource-based view of strategic alliances and firm value in the electronic marketplace. Journal of Management, 30(1), 7-27.

Parker, P. M., \& Tavassoli, N. T. (2000). Homeostasis and consumer behavior across cultures. International Journal of Research in Marketing, 17(1), 33-53.

Prajogo, D., \& Olhager, J. (2012). Supply chain integration and performance: The effects of long-term relationships, information technology and sharing, and logistics integration. International Journal Production Economics, 135, 514-522b.

Roussel, P., Durrieu, F., Campoy, E., \& Akremi, A. (2002). Méthodes d'équations structurelles: Recherche et applications en gestion. Paris: Editions Economica.

Rutner, S. M., \& Langley, Jr. C. J. (2000). Logistics value: definition, process and measurement. The International Journal of Logistics Management, 11(2), 73-82.

Saad, M. (2006). An investigation of supply chain performance measurement in the Indian automotive sector. Benchmarking: An International Journal, 13(1/2), 36-53.

Saeed, K. A., Malhotra, M. K., \& Grover, V. (2005). Examining the impact of interorganizational systems on process efficiency and sourcing leverage in buyer-Supplier dyads. Decisions Sciences, 36(3), 365-396.

Schumacker, R. E., \& Lomax, R. G. (2004). A beginner's guide to structural equation modeling (2nd ed.). Mahwah, N.J.: Lawrence Erlbaum Associates.

Schurr, P. H. (2007). Buyer-seller relationship development episodes: Theories and methods. Journal of Business and Industrial Marketing, 22(3), 161-170.

Sheu, C., Yen, H. R., \& Chae, D. (2006). Determinants of supplier-Retailer collaboration: Evidence from international study. Journal of Operations and Productions Management, 26(1), 24-49.

Simatupang, T. M., \& Sridharan, R. (2002). The collaborative supply chain. International Journal of Logistics Management, 13(1), 15-30.

Spekman, R. E., Kamauff, J. W., \& Myhr, N. (1998). An empirical investigation into supply chain management: A perspective on partnership. Supply Chain Management: An International Journal, 3(2), 53-67.

Stank, T. P, Keller, S. B., \& Daugherty, P. J. (2001). Supply chain collaboration and logistical service performance. Journal of Business Logistics, 22(1), 29-48

Steenkamp, J. B. E. M., \& Burgess, S. M. (2002). Optimum stimulation level and exploratory consumer behavior in an emerging consumer market. International Journal of Research in Marketing, 19(2), 131-150.

Strauss, A., \& Corbin, J. (1990). Basics of qualitative research: Grounded theory procedures and techniques. London: Sage.

Thomas, D., \& Ranganathan, C. (2005). Enabling e-business transformation through alliances: Integration social exchange theory and institutional perspectives. Proceeding of the 38th Hawaii, International Conference on System Science. Big Island, Hawaii.

Verwaal, E., \& Hesselmans, M. (2004). Drivers of supply chain network governance: Explorative study of the Dutch chemical industry. European Management Journal, 2(4), 442-451.

Wagner, S. M., \& Bode, C. (2008). An empirical examination of supply chain performance along several dimensions of risk. Journal of Business Logistics, 25(1), 307-325. 